\section{Dinucleotide repeat polymorphism at the D19S75 locus}

James L.Weber*, Clarisse Kappel, Paula E.May and Anne E.Kwitek Marshfield Medical Research Foundation, 510 North St. Joseph Avenue, Marshfield, WI 54449, USA

Source/Description: A human genomic Sau3AI fragment from a large insert human chromosome 19-specific phage library (LL19NL01) was cloned into mp18 and selected by hybridization to $\operatorname{poly}(\mathrm{dC}-\mathrm{dA}) \cdot \operatorname{poly}(\mathrm{dG}-\mathrm{dT})$. The cloned fragment was designated Mfd13. Sequencing of Mfd13 provided the information necessary for polymerase chain reaction primer synthesis. The clone length was $242 \mathrm{bp}$, and the predicted length of the amplified fragment was $143 \mathrm{bp}$.

Primer Sequences: ATTAATCCATCTAAAAGCGAA (CA strand); TTCCCTTTGCTCCCCAAACG (GT strand).

Frequency: Estimated from 100 chromosomes of unrelated CEPH family grandparents (Caucasians). PIC $=0.61$.

$\begin{array}{llll}\text { Allele(bp) } & \text { Frequency } & \text { Allele(bp) } & \text { Frequency } \\ 152 & 0.01 & 144 & 0.12 \\ 150 & 0.11 & 142 & 0.02 \\ 148 & 0.56 & 136 & 0.05 \\ 146 & 0.13 & & \end{array}$

Chromosomal Localization: Assigned to chromosome 19 using DNA templates isolated from panels of somatic cell hybrids.

Mendelian Inheritance: Co-dominant segregation was observed in 14 two generation families.

Other Comments: Conditions for the amplification reactions were as described in the reference except that samples were processed through 27 temperature cycles consisting of $1 \mathrm{~min}$ at $94^{\circ}, 2 \mathrm{~min}$ at $55^{\circ}$ and $2 \mathrm{~min}$ at $72^{\circ}$. Sizes of the alleles were determined by comparison to mp 8 DNA sequencing ladders and were the averages of the sizes of the GT-strand and CA-strand bands. The dinucleotide repeat sequence in Mfd13 was of the form $(\mathrm{CA})_{4} \mathrm{CGCG}(\mathrm{CA})_{19} \mathrm{C}$. The sequence of $\mathrm{Mfd} 13$ has been submitted to GenBank.

Acknowledgements: This work was supported by the Marshfield Clinic and NIH grant GM41773.

References: Weber,J.L. and May,P.E. (1989) Am. J. Hum. Genet. 44, 388-396.

\section{Dinucleotide repeat polymorphism at the D22S156 locus}

\author{
James L.Weber* and Paula E.May \\ Marshfield Medical Research Foundation, 510 \\ North St. Joseph Avenue, Marshfield, WI 54449, \\ USA
}

Source/Description: A human genomic AluI fragment was cloned into $\mathrm{mp} 10$ and selected by hybridization to poly $(\mathrm{dC}-\mathrm{dA}) \cdot \operatorname{poly}(\mathrm{dG}-$ dT). The cloned fragment was designated Mfd33. Sequencing of Mfd33 provided the information necessary for polymerase chain reaction primer synthesis. The clone length was $115 \mathrm{bp}$, and the predicted length of the amplified fragment was $106 \mathrm{bp}$.

Primer Sequences: AGCCTGGGAGTCAGAGTGA (CA strand); AGCTCCAAATCCAAAGACGT (GT strand).

Frequency: Estimated from 116 chromosomes of unrelated $\mathrm{CEPH}$ family grandparents (Caucasians). PIC $=0.64$.

$\begin{array}{llll}\text { Allele(bp) } & \text { Frequency } & \text { Allele(bp) } & \text { Frequency } \\ 110 & 0.01 & 102 & 0.24 \\ 108 & 0.04 & 98 & 0.01 \\ 106 & 0.27 & 96 & 0.01 \\ 104 & 0.42 & & \end{array}$

Chromosomal Localization: Assigned to chromosome 22 using DNA templates isolated from panels of somatic cell hybrids.

Mendelian Inheritance: Co-dominant segregation was observed in 15 two generation families.

Other Comments: Conditions for the amplification reactions were as described in the reference except that samples were processed through 27 temperature cycles consisting of $1 \mathrm{~min}$ at $94^{\circ}, 2 \mathrm{~min}$ at $55^{\circ}$ and $2 \mathrm{~min}$ at $72^{\circ}$. Sizes of the alleles were determined by comparison to mp8 DNA sequencing ladders and were the averages of the sizes of the GT-strand and CA-strand bands. The dinucleotide repeat sequence in $\mathrm{Mfd} 33$ was of the form $(\mathrm{AC})_{14} \mathrm{AT}(\mathrm{AC})_{13}$. The sequence of $\mathrm{Mfd} 33$ has been submitted to GenBank.

Acknowledgements: This work was supported by the Marshfield Clinic and NIH grant GM41773.

References: Weber,J.L. and May,P.E. (1989) Am. J. Hum. Genet. 44, 388-396. 